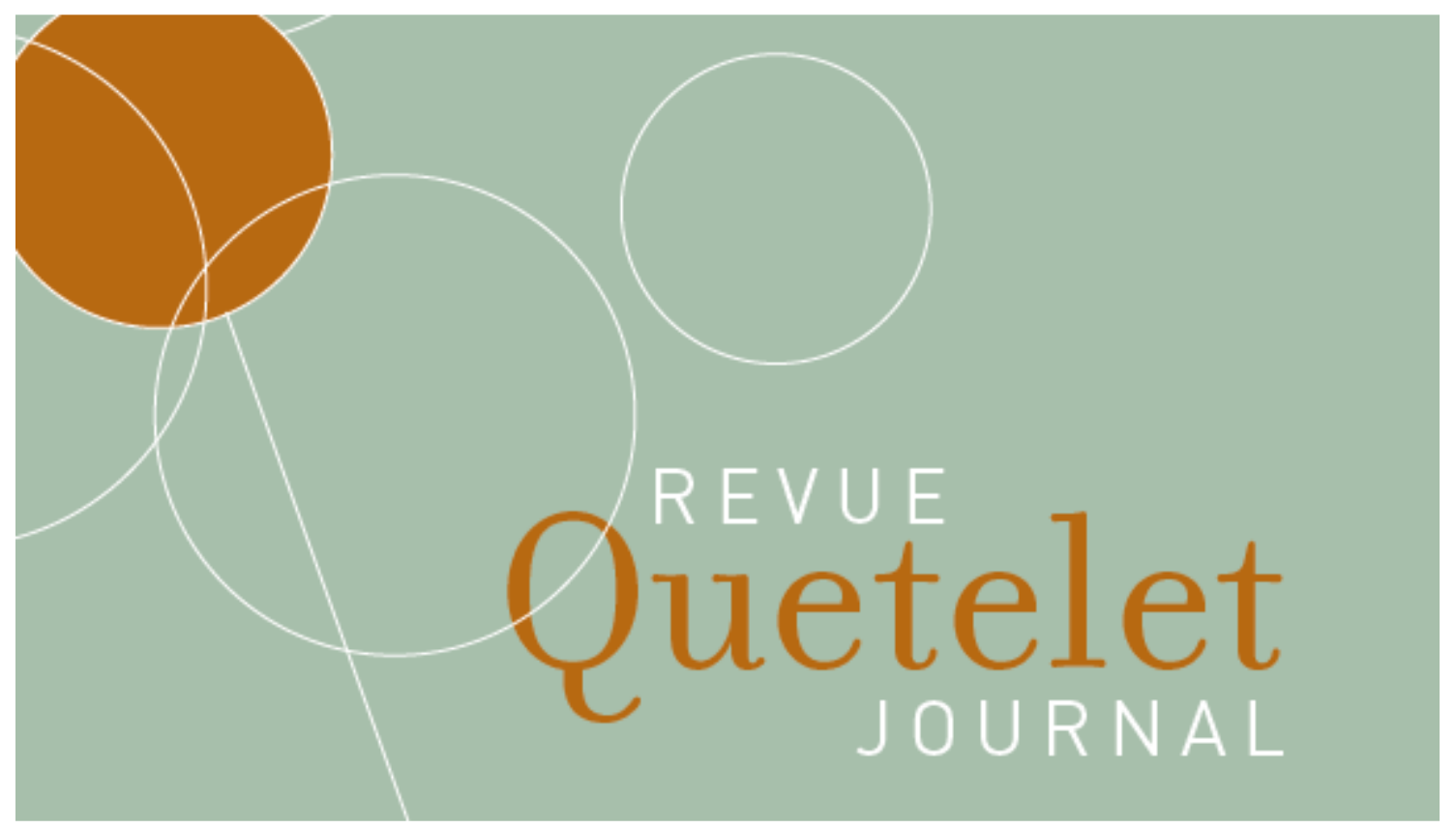

Vol. 1, n² 1, avril 2013, pp. 7-31

DOI : 10.14428/rqj2013.01.01.01

ISSN: 20349378

\title{
Moving migration into century 21
}

\author{
Michael J. White
}

C2013 Michael J. White

This work is licensed under a Creative Commons Attribution-NonCommercial 4.0 International License. You can share, adapt the material for non-commercial purposes provided that you give appropriate credit and indicate if changes were made. For details see https://creativecommons.org/licenses/by-nc/4.0/

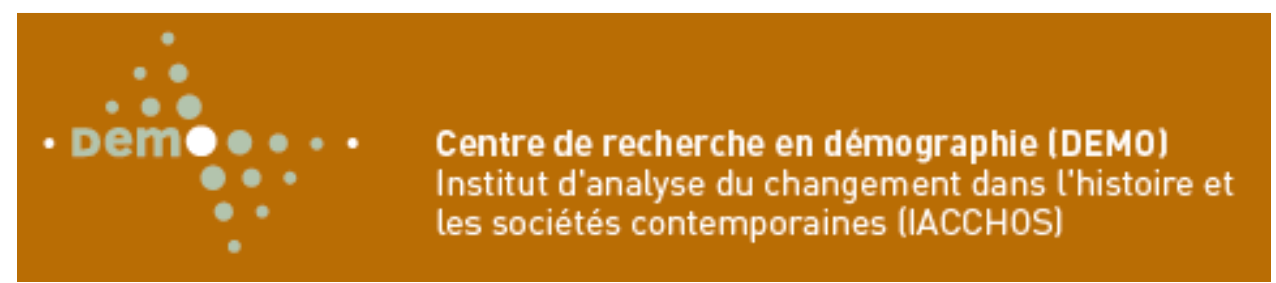





\title{
Moving Migration into Century 21
}

\author{
MichaEL J. WHITE ${ }^{1}$
}

\section{Résumé}

Cet essai présente les tendances récentes des migrations et de l'urbanisation dans les pays du Sud à la lumière des tendances historiques et contemporaines des pays du Nord. Les perceptions de la migration et de l'urbanisation sont importantes en ce qu'elles peuvent orienter les mesures politiques au plus haut niveau, et pourtant les enjeux de la répartition de la population sont parfois mal compris. Malgré les difficultés à mesurer correctement la migration et l'urbanisation, ces phénomènes révèleront beaucoup sur les inégalités sociales, le développement économique et les changements de l'environnement au cours du 21ème siècle. Dans le même temps, les effets de la migration et de l'urbanisation ne sont pas nécessairement simples ni uniformes dans tous les pays. La migration rurale-urbaine contribue à la croissance urbaine mais le rôle de l'accroissement urbain, de la migration urbaine-rurale et de la migration de retour ne doit pas être négligé. Chercheurs et politiques auraient tout intérêt à incorporer migrations nationales et internationales dans des cadres conceptuels élargis, notamment en ce qui concerne les questions d'assimilation et d'intégration sociale. Il est nécessaire de rassembler plus de données sur les tendances de la mobilité géographique et de ses déterminants, quelles que soient les frontières nationales ou internationales traversées.

\section{Mots-clés}

Migration interne, urbanisation, migration internationale, assimilation, intégration.

\section{Summary}

This essay analyzes current trends in migration and urbanization for the contemporary Global South in light of historical and recent trends in the Global North. Perceptions of migration and urbanization are important in that they may drive policy at the highest levels, yet population redistribution is sometimes inadequately understood. Despite continuing challenges regarding adequate measurement, urbanization and migration

1. Department of Sociology, Population Studies and Training Center, Brown University, Providence, RI USA. 
will have much to say about social inequality, economic development, and environmental change in the 21st century. At the same time, the effects of migration and urbanization are not necessarily simple nor are they uniform across countries. Rural-to-urban migration contributes to urban growth but the role of natural increase, of urban-tourban migration and of return migration should not be neglected. Scholars and policymakers will benefit by expanding conceptual frameworks to incorporate both international and internal migration, most notably with regard to assimilation and social integration. More data need to be gathered on trends in geographic mobility and its determinants, whatever the internal or international borders crossed.

\section{Keywords}

Internal migration, urbanization, international migration, assimilation, integration.

\section{Introduction: The 21st Century Context ${ }^{2}$}

Population redistribution is likely to be a highly visible component of world demographic dynamics in the 21st century. Crucially important to understanding geographic mobility and its implications for well-being and for policy-making is the recognition of the intertwining of internal migration, international migration, and urbanization. This interconnectedness of geographic mobility dynamics is very much the case for all regions of the world, albeit the factors will differ depending on geography and a region's progress through the demographic transition.

In this essay I offer some observations and analysis of migration and urbanization for the contemporary Global South, reflecting current trends in the light of the world and higher income regions. I argue that, even given the growing importance of migration and urbanization, these phenomena remain underappreciated or their manifestation poorly understood. For example, in a 2011 collection within Science on the occasion of the world passing the 7 billion mark, a review article on population policy in the developing world makes no mention of migration or urbanization (Bongaarts, Sinding, 2011). Similarly text accompanying the World Population Data sheet in 2011 made virtually no mention of urbanization, and only discus-

2. This paper has its origins in the Keynote address of the Quetelet Seminar at the University of Louvain La Neuve, 16 Nov 2011. I am grateful to Fartun Dirie for capable research assistance in preparing graphical material. 
sed international migration in the setting of the United States (Population Reference Bureau, 2011).

More encouraging perhaps is that the 2011 State of World Population devoted multiple chapters to issues of population distribution, including one specifically on migration in which international and internal migration both received treatment (United Nations, 2011). One chapter, entitled «Decision to move: The power and impact of migration» suggests the salutary effects of migration for the movers and for their societies as a whole. The subsequent chapter, «Planning ahead for the growth of cities», takes the tack of assuming that cities will grow (through migration) and that the better policy option is to plan for that eventuality and some of its very clear challenges. This contrasts with an often-voiced alternative view of the need to slow down or even reverse urban growth.

While my comments here emphasize the 21st Century experience of the Global South, they are by no means unconcerned with historical events and upcoming trends in the Global North. Whereas the high-income countries («more developed regions» in UN parlance) are already very highly urbanized, these regions are not likely to be static with respect to population distribution. High income nations are likely to be the real or desired destinations for international migrants, both from other high-income countries (witness EU country-to-country migration) or from the Global South (consider migration to Australia from China, India and a number of other origins). Moreover, within these countries, population redistribution-across regions and differentially up and down the urban hierarchy - is likely. The progress of the demographic transition has already reduced the annual contribution of natural increase to world population growth - from about $2.2 \%$ annually in the 1960 s to $1.3 \%$ annually in the first decade of the 2000 s and this is, in turn, likely to raise the importance of geographic mobility at several scales, from interregional movement to international movement (UN, 2011). Urbanization, of course, has been closely linked to the demographic transition and the many changes in society that accompany it (Dyson, 2010).

Perceptions of migration and urbanization are important in that they may drive policy at the highest levels. Note that at the time of the world passing the 7 billion population threshold, a high United Nations official, expressed a view, probably held by many, regarding the policy discussions of the years to come: 
«At the same time, he [Executive Director of the UN Population Fund (UNFPA) Babatunde Osotimehin] highlighted the need to give ageing populations in many parts of the world a life of dignity, and to tackle the rapid urbanization and migration which many countries have to face» (UN, 2011: www.unfpa.org/public/home/ news/pid/8769).

While current commentary, such as this above, tends to focus on lower-income countries, population redistribution will deserve the attention of policy makers at all levels of development in the decades to come. In some highincome countries, and especially in some middle-income countries, rates of urban growth are likely to slow, at least compared to their recent trends. Some societies may see significant population increment from international migration. Environmental adjustments, particularly in the face of global warming, may shift the relative attractiveness of coastal and inland locations. Population has always redistributed in response to livelihood opportunity, and the changing fortunes of different regions - natural and human resources, amenities - are likely to spur internal migration, even if overall population growth slows.

Figure 1, taken from United Nations sources, recapitulates the conventional picture of urbanization trends by world region. But this general picture obscures some important nuances and trends within regions. The UN has estimated that the world has crossed the half-urban threshold, and while this benchmark is often mentioned, there remains much ambiguity and uncertainly with respect to the world's urban population. First, the very definition of «urban» itself is fraught with inconsistency. Perusing the periodic UN publication, World Urbanization Prospects, will indicate that urban thresholds (for settlement size) vary from as low as 2'000 persons in some nations to as much as $50^{\prime} 000$ in others. The lack of a uniform settlement size threshold, along with the genuine challenge of deciding (for any threshold) about settlement boundedness and density, make «urban» far less consistently defined than statistical compendia would suggest. The accuracy of estimation procedures that give rise to the world half-urban has been questioned. Bocquier, for instance, has demonstrated that the UN regression-style methodology leads to biased overestimates of urbanization trends (Bocquier, 2005; see also Bocquier, Mukandila, 2011; Brockerhoff, 1999). Bocquier's work further recognizes the variety of country-specific definitions of urban, and the problematic failure (by the UN and other projection methods) to take this heterogeneity into account. Thus, the lack of coherence in urban definition not only muddies our understanding of contempo- 
rary snapshots of urban living, but also complicates, confuses, and often biases our understanding of urban trends.

By 2000 the vast majority of the population in Europe, North America, and Oceania (UN categories) could be considered «urban», and it is shown as such in Figure 1. The playing out of urbanization does not at all mean that population distribution is static in these regions. Some major urban areas in the Global North have experienced significant depopulation of their city cores, while others have maintained some stability or even show some population growth due to gentrification or new urban in-migration.

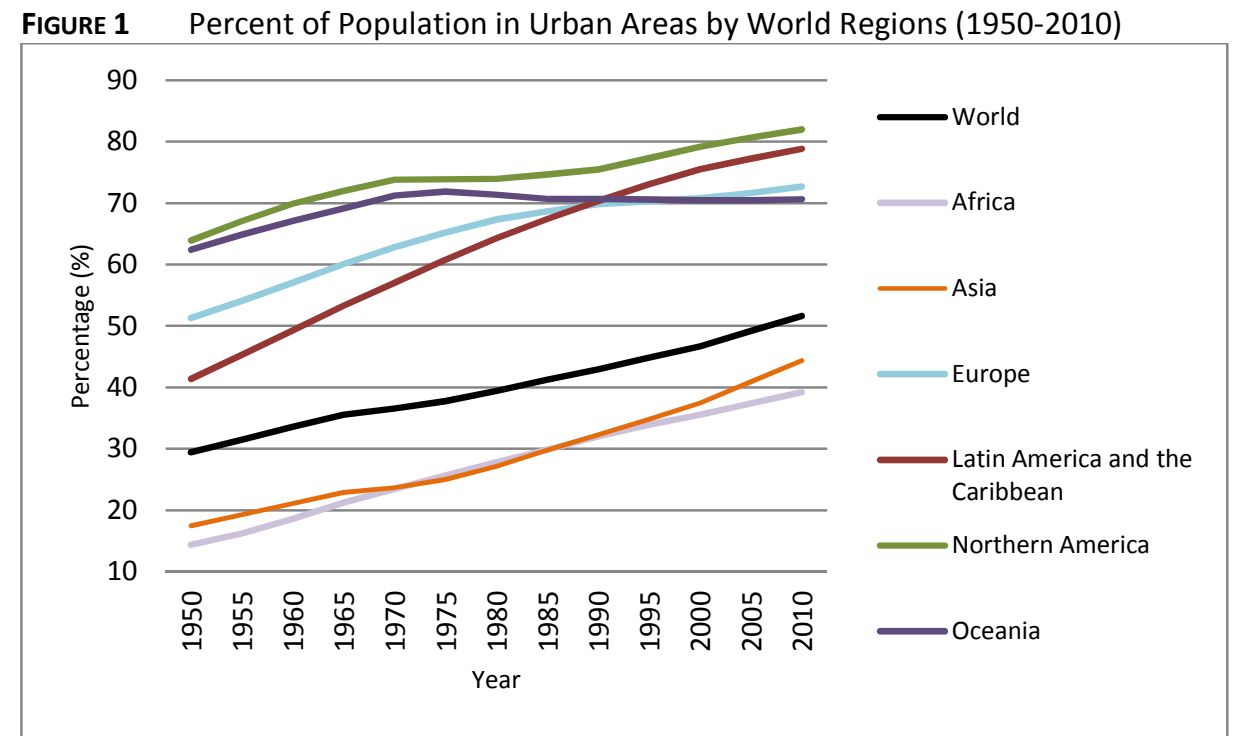

Source: UN World Urbanization Prospects 2011 [online data].

Urbanization and migration trends in middle-income countries may be particularly interesting, yet difficult to assess. Historical precedent would suggest continued increases in the urban share of the population, although at least one recent paper indicates that African urbanization may stagnate at less than half the population (Bocquier, Mukandila, 2011). A decline in intercensal urban growth rates can already be seen in some of the trends for larger urban agglomerations of the world in the last half century. Figure 2 presents the 50-year trend in intercensal growth rates in several of the 
world's largest cities beginning in 1960. Urban agglomerations depicted from the Global North (Paris, London, Moscow, New York) already had modest growth rates by mid-20th century and these rates remained relatively low through 2010. Large cities in Latin America, a region high level of urbanization, exhibited declining intercensal growth rates over the half century; witness the paths traced by Lima and Sao Paolo. More than half of the 30 largest urban agglomerations by 2010 are located in Asia. Several experienced rapid growth during some interval within the half-century period, but here too, many of these large urban areas experienced declining intercensal growth rates with time. (The record for Chinese cities is confounded by territorial reclassification that makes for swings in intercensal comparisons.) Jakarta and Mumbai tell a parallel story; both grew at over $4 \%$ annually in the first two decades of the period, but had declined to under $2 \%$ by the first period of the 21st century. Lagos is the only top-thirty city from sub-Saharan Africa, the world's least urbanized region. But here, too, growth rates have declined over time, while remaining above $4 \%$ for the 2000-10 decade. One also finds that 11 cities listed among the 30 largest urban agglomerations for 1960 had fallen out the top thirty by 2010; eight of these (excepting three in greater China) were in the Global North.

None of this information about urban size and growth trends comes as a surprise to students of cities and urbanization. Some of the high levels of urban growth at lower levels of economic development are attributable to natural increase (Preston, 1979). Further, some of the decline in growth rates is due itself to the growth of the urban denominator and the shrinking share of rural-origin population (Montgomery et al., 2003). In any case, such figures remind us of the important need for demographic accounting as the 21st century proceeds. Leaving migration and urbanization off the radar screen is unwise for an understanding of the demography of the 21st century.

Despite the serious problems of measurement, the interplay of various components of population dynamics across the earth's surface in the 21st century will have much to say about social inequality, economic development, and environmental change. To be sure, a better understanding of distribution and redistribution of people across the globe, both within and between national boundaries, offers much to scholars and policy-makers in the decades to come. We need to improve our conceptualization, data and analysis in order to move migration into the 21 st century. In the remainder of this 
essay, I take note of some key issues for migration scholars and policy makers. I concentrate on four questions (themes): (1) Migration Unprecedented? (2) Mega Cities with Mega Problems? (3) Assimilability? And (4) Migration, Urbanization, and Livability. I also take note of several papers that were selected for publication from the 2011 Quetelet Seminar, and situate them in light of this conversation. I conclude with speculative thoughts on whether the historical trends of the Global North have contemporary lessons for the Global South.

FIGURE 2 Intercensal Growth Rate for 30 Selected Large Urban Agglomerations (1960-2010)

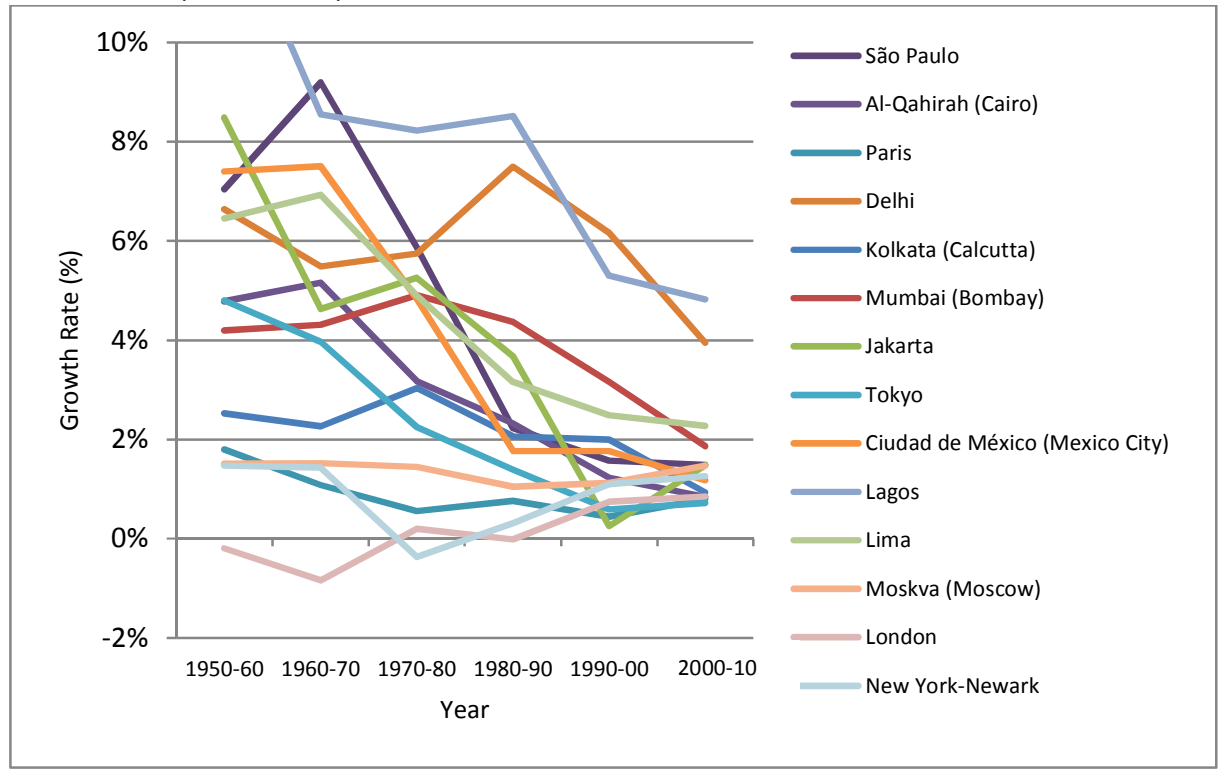

Source: UN World Urbanization Prospects 2011 [online data].

Note: Value for Lagos $1950-60=13.03 \%$.

\section{Migration Unprecedented? International and Internal}

The world is on the move to be sure, but is the globe experiencing an unprecedented amount of migration? According to UN estimates, about 214 million persons are living outside of their country of birth (UN Population 
Division, 2011). This amounts to about 3\% of the world's population. The absolute number of international migrants is of course large - and probably unprecedented - but the scale of present-day long distance migration compared to other historical epochs is a bit harder to discern. UN Population Division estimates indicate that between 1960 and 1980 the share of international migrants (among the world's population) actually declined from $2.5 \%$ to $2.2 \%$, before climbing to $2.9 \%$ in 1990 (UN, 2006). Earlier historical epochs also experienced significant migration. The spread of population (both voluntary and involuntary movement) from the Eastern to Western hemisphere from the 16th through early 20th centuries, although not recorded by conventional demographic procedures, was substantial.

We are in even less firm ground when trying to consider the scale of internal migration. There are no regularly produced world-wide estimates, and even if there were, shifting and inconsistent definitions of migration - with respect to time and space both - militate against comparable statistical compendia. Of course, analysts are further hampered by the outright lack of meaningful extant migration data for a number of populations.

Even despite these definitional and administrative challenges, there is much to be gained by bringing international and internal migration into the same conceptual framework. While the scholarly and policy literatures have proceeded somewhat independently, both forms of mobility include determinants and consequences of similar kinds. Equally importantly, understandding one kind of movement can inform understanding of the other. Both flows involve significant redistribution of labor, with individuals generally seeking greater opportunity at the destination. Both flows also can involve involuntary moves of persons, some as refugees and some as internally displaced persons. Often flows, especially those of labor migrants, are directed toward urban areas, whether to a medium or large urban place within the country of origin (residence), to another urban place within the region, or to another world region.

The crossing of a national political boundary is crucial, but this key distinction should not obscure some of the similarities and regularities of any long-distance geographic mobility. Although much historical movement of populations was quite localized, there were also substantial intra-continental movements (within Europe and North America) across territory that is now recognized with an international (and regulated) border (McNeill, Adams, 1978). 
Consider further the case of contemporary sub-Saharan Africa. Of the world population around 2010, there were about 30.6 million international migrants with African origins (MPI, 2012). On the order of half of these migrants reside in other countries within the continent, with Europe is the largest intercontinental destination. (According to these estimates, nearly onethird of the 30.6 million international migrants originate in Northern Africa.) A very large proportion of the flow of intra-continental, international migration is within the several countries of Western Africa; of the 12.8 international migrants within Sub-Saharan Africa, these data indicate that $47 \%$ move across West African states within the sub-region. The concentration among sub-regions has been long-standing. A substantial West African migration system was identified in demographic calculations dating to the 1960s and 1970s (Zachariah, Conde, 1981; Makinwa-Adebusoye, 1992). Historical analyses point to long-standing trade and cultural connections that span contemporary national borders. The existence of long-standing migratory flows that pre-date the political subdivisions of West Africa certainly help bring home the point of the interconnectedness of internal and international migration. What could once be called internal migration is now international migration.

Additional evidence of parallels is provided by Hein de Haas, who draws attention to the Africa-Europe migration system (Hein de Haas, 2008). He calls attention to the discourse over this migration and some of the several key misperceptions of its determinants, especially that surrounding irregular migration. He argues that African Migration to Europe «is not so massive, new or so driven by 'African misery' as is commonly assumed» (Hein de Haas, 2008, p. 1306). By contrast, Hein de Haas, not only rebuts some of the conventional myths, but also points to the historical rootedness and economic motivation of this migration. Perhaps some observers will see remarkable parallels between this migration and the irregular migration in North America (Mexico-US especially) and within China (internally «floating» population).

All this does suggest the value - for scholars and policy-makers both - of looking at population movement with a uniform lens. In this way learn more about similarities (and genuine differences) in these flows of persons, and how best to accommodate or respond to them. 


\section{Mega cities with mega problems?}

The perception - even within the scientific community - is often one of «exploding» or unmanageable cities. Consider the following:

«Without careful investment and planning, mega-cities (those with more than 10 million inhabitants) will be overwhelmed with burgeoning slums and environmen-

tal problems» (Ash et al., Science, 8/02/08).

The comment raises the specter of an unhealthy urban setting deleterious for society as a whole. Certainly the world now has several megacities. How should we think about these cities, their growth and demographic dynamics in the 21st Century? Again perceptions often get away from demographic reality. To be sure contemporary urbanization, especially in some low-resource settings, places challenges on society. At the same time, we should understand some key features of contemporary urbanization.

While megacities garner much attention - after all, they are huge agglomerations - they still capture a modest share of the world's urban population. For 2000 it was estimated that there were 16 megacities worldwide (Montgomery et al., 2003). In developing countries (containing 12 of these cities) the share of urban population located in megacities was estimated to be $12 \%$ (Montgomery, 2008). Large fractions of the population continue to live in urban agglomerations of intermediate size.

In the concern about rapidly growing cities, especially in the Global South, the role of natural increase is often overlooked. Technical demographic analysis by the United Nations indicates that natural increase (excess of births over deaths) accounted for at least half of urban growth in a substantial share of countries of Africa, Asia, and Latin America (UN, 2008). Furthermore rates of urban growth (as opposed to urbanization, the share of population in cities) tend to decline with time, as was discussed above (see again Figure 2). Seen in historical perspective some of the late 20th and early 21st century urban growth rates are not out of alignment with historical experience of early industrial transformation in the US or Europe (Montgomery et al., 2003). Thus, demographic dynamics - both the shifting size of the rural and urban base for the calculation of rates and the shift in urban childbearing incentives - serve to dampen the rate of urban growth. Several Asian megacities witnessed significant declines in urban growth rates in the last 
few decades of the 20th Century. The same is true of the Latin American mega cities of Mexico, Buenos Aries, and Sao Paolo.

Most accumulated evidence suggests strongly that urbanization confers benefits. As stated by the Commission on Growth, «Urbanization and growth go together» (Annez, Buckley, 2006). Again, while the contribution of migrants (both internal and international) to urban growth has often been seen as problematic, research generally establishes a positive link between urbanization and economic development (Dyson, 2010), although certain policies may hinder that connection (Duranton, 2006). In developing settings internal rural-urban migration can generate flows of remittances to the origin community, much in parallel with international remittance flows (Tacoli, 2008).

During the standard process of development and of urbanization the net balance of population movement is in favor of urban areas. Much of what is known (or assumed) however is simply cast in terms of rural and urban territory generally, and we know less about movement patterns within the various levels of urban settlement. Evidence to date suggests that migrants typically move «up» the urban hierarchy. By moving up the urban hierarchy, we include both moves from rural to urban areas, and importantly, moves from smaller to larger urban agglomerations. Thus urban-urban migration can be up the hierarchy, i.e. to larger places, even if it is not a move directly from countryside to large city. For example, during China's rapid urban growth in the 1990s, moves out of the «town» level of settlement, were $23 \%$ to other «towns», $26 \%$ to rural areas (thus «down» the hierarchy) and $51 \%$ to cities («up» the hierarchy) (White, Jiang 2008). The phenomenon is not necessarily universal, however. Evidence on this point for West Africa is only partially parallel. Drawing on a set of 7 country-specific surveys that endeavor to capture migratory behavior in a longitudinal framework, Bocquier and Traoré find that capital cities exhibit superior attractiveness in most cases for both male and female migrants. Furthermore, international migrants originated in rural areas (Bocquier, Traoré, 2000).

Without discounting the sometimes challenging consequences of migration, both internal and international, the move is usually beneficial for the migrant and his or her household or network (White, Lindstrom, 2005). Furthermore, the urban transition that such migration promotes may help with poverty reduction and environmental sustainability (Martine, 2011). Most migrants report gains from the relocation. Similarly, migration allows labor 
to move to places of superior return, and thereby, produce benefits for the wider economy and society. The literature on internal migration - considering free movement across sub-national administrative boundaries - would argue for the benefits of such moves. The argument has been made for the case of international moves as well (Pritchet, 2006). There are individuals, often lower skilled native-workers of the host societies, who benefit less or suffer more from the arrival of international migrants. Clearly, there are issues of social stress, equity, and service planning in the destination societies that arrive with the population flows themselves.

While migration certainly feeds urban growth, so does natural increase. Often less appreciated is that migration can work to indirectly retard overall growth. By shifting population up the urban hierarchy, more persons are exposed to incentives (both pecuniary and normative) that serve to lower rates of childbearing and overall urban growth. Some empirical evidence with longitudinal data seems to bear this out, even in a modestly urbanized setting of coastal Ghana (White et al., 2008). Ironically, policymakers often express a wish to retard urban growth by discouraging migration (United Nations, 2008).

Although one must be cautious not to overemphasize the current and future position of megacities, there are important differences with the past (NAS, 2003). It does appear that the scale of urbanization has shifted toward the «larger» end of the scale. Thus many urbanites - including those in developing countries - are living in urban settings at a larger scale than was the case before. Thus contemporary Lagos or Shanghai is relatively large for its level of economic development compared to London or New York of an earlier era.

\section{Assimilability?}

A long-standing concern regarding migration (and concurrent urbanization), and one that directly ties the Global North to the Global South, is the ability of the receiving society to successfully absorb the new arrivals. Much worried discourse surrounds the issue of the integration international migrants from low-income societies to high-income settings. But note again that the issue of migrant integration applies in multiple settings: it is cer- 
tainly relevant for the case of rural-urban migrants to developing country cities. Whatever the receiving setting «success» would seem to involve both a net societal benefit - economic growth perhaps - arising for the population redistribution, and socioeconomic improvement of the migrants themselves. While it is undeniably clear that resettlement takes places with considerable strain for both host community and migrant community, there is also evidence that the trajectory of change is often an optimistic one for both, as well.

The experience of urbanization and urban growth discussed above carries over here to assimilability. In most settings the migration is set and continued in motion due to the geographical differentials in opportunities that have arisen. Migrants generally regard themselves as better-off for having made the moves (White, Lindstrom, 2003). And as a number of studies have shown migration and concomitant urbanization can be associates with rising levels of living standards (Spence, Annez, Buckley, 2009).

The notion of «assimilation» per se is probably more readily attached to the matter of the absorption of international migrants by the host society. In the US the terminology would favor «assimilation», while in Europe it favors «integration», although the meanings are not strictly interchangeable (Alba, Sloan, Sperling, 2011). For sure, receiving societies have had numerous doubters throughout their history regarding the successful adaptation of immigrants. In the USA, for instance, this is seen in the activities and writing of the Dillingham Commission's several reports in the wake of the great wave of 19th and early 20th century European immigration. Contemporary US scholarly writing has questioned the assimilability of newcomers (Huntington, 2004), and this is manifest as well in comments from ordinary citizens (Bean, Lee, 2010). Certainly the continuing US debates over immigration reform reflect currents of interpretation about how well new migrants will mix in. On the other hand, much research shows that immigrants do succeed (Waters, Jimenez, 2005), and that in both contemporary and historical experience evidence of assimilation or «success» can be seen within the first generation as well as across subsequent generations (Myers, Cranford 1998; White, Mullen, 2012). The experience of the long-standing countries of immigration, e.g. Australia, Canada, United States, has arguably generated the longest-running academic research archive on immigrant adaptation. Now research on other receiving societies such as contemporary European Union countries - including longitudinal research that looks at socioeco- 
nomic attainment of the second generation - is beginning to accumulate (Barban, White, 2011; Alba, Sloan, Sperling, 2011). As part of the evolution of policy response in newly receiving countries, once liberal policy positions, such as in Sweden, have come under increasing scrutiny as the first and second generation share of the population has increased (NYT, 2011).

Low-income societies are the origins of many international migrant flows. At that same time, within these societies are there substantial flows of internal migrants that generate companion consideration of assimilability and integration. At a minimum, these migrants raise questions of economic and social adaptation in urban areas, places usually so different from their rural origins. Often, as with international migration, ambivalence applies, with migrants intending urban life to be temporary (at least upon arrival) but in the end settling and giving rise to another generation of urban natives.

Internal migration in developing settings may have more aspects of international migration than is sometimes recognized. Sometimes urbanward migrants are from a different linguistic or cultural group, and thus issues of adjustment quite parallel to the case of international migrants can arise. African internal migrants and indigenous migrants within Latin America constitute cases where there may be considerable distance between sending and receiving community, even though no international border has been crossed.

Migration and adjustment are often intertwined with an administrative component, and this can take place for both international and internal migration. The case of international migration is perhaps obvious, as those who enter the host society without proper documentation become illegal or unauthorized migrants. The parallel does exist for internal migration. Consider, for example, the case of the «floating» population in China. As Poston and Zhang write regarding China, «the size of the temporary migration streams is much larger than the size of the permanent migration streams. Considering only the ten largest migration streams, the temporary streams are on average 14 times larger than the permanent streams» (Poston, Zhang, 2008). These internal migrants - a number larger than most international migration streams - often do not have fully authorized residence ( $h u$ $\mathrm{kou}$ ) in their destination city, raising some interesting parallels with international unauthorized migrants to the Global North.

Remittances form a crucial part of the migration and development picture. To be sure they are substantial in size. Recent estimates have placed the 
magnitude of the international remittance flow to be $\$ 167$ billion for 2005 , although likely underestimated (World Bank, 2006). International remittances likely serve to reduce poverty in the Sub-Saharan setting. Skeldon has pointed out, however, that observers may be focusing on international migratory flows (in which small fractions of the population participate) to the exclusion of other concerns (Skeldon, 2008). We should be mindful that substantial flows of resources occur within countries as a consequence of internal migration, although the magnitude of these flows is not well measured at all.

All in all, however, international migration has become a distinctive feature of a wide array of high income societies, and in many cases, tightly linking them to conditions in lower income societies. Despite the challenges of integration or assimilation, and the significant political strife that can accompany the intermixing of socioeconomic origins and cultures, there is plenty of evidence to suggest that the migration is beneficial.

\section{Migration, Urbanization, and sustainability}

This final theme is so broad as to be almost out of reach, but I wish to comment on just a few aspects of livability - or sustainability - for the future of migration and urbanization. Sustainability is a contemporary buzzword, for sure, and seems to encompass an uncountable range of meanings, depending on the circumstance. Here I will concentrate on environment and health.

Migration is dramatically implicated in circumstances of natural environment disturbance and political strife (Tacoli, 2010). War, civil strife, and natural disasters are usually cataclysmic events which suddenly displace large numbers of individuals. Often these individuals are impoverished and have only modest personal and household capacity for addressing the immediate circumstances and recovery. Important - although not well accounted for is the fact that, once again, flows of migrants in such circumstances are both internal and international. International refugees and persons displaced internally (sometimes termed environmental refugees in the case of natural disasters) are distinct populations in need. While it may be clear that such persons have different reasons for their movement and hence invoke different policy responses, it should also be recognized that many of these emer- 
gency relocations become long-term or even permanent resettlements. Thus, they bring about many of the same concerns that arise with the case of other migratory streams.

And just as population redistribution is often the result of environmental disturbance, population redistribution is often seen as a key driver of environmental degradation. Deforestation through urbanization and other settlement extensions, coastal environmental stress, and air pollution are just a few examples of environmental threats that are linked to migration and urbanization. Consider, for example this recent assessment, which makes mention of the directional aspect of migration-environmental links:

\footnotetext{
«It is also at the regional scale that land-use changes driven by and resulting from population movement are most apparent. Perceived opportunities in growing urban centers and lack of opportunities in rural settings, resulting from degraded landscapes and imbalanced economic systems, have made the migrations since the second half of the 20th century the greatest human-environmental experiment of all time. In China alone, 300 million more people likely will move to cities, transforming their home landscapes and continuing an already unbelievable juggernaut of urban construction» (Grimm et al., 2008).
}

Much of this concern for population-environment interaction operates at a very high level of aggregation, i.e. attribution of general environmental deterioration to change in total population size (or movement). At a smaller scale the nature of the effects may manifest themselves somewhat differently. While the links are acknowledged, the precise causal mechanisms and paths of influence are difficult to identify.

Some analysts see salutary effects of migration and urbanization for the daunting 21st century environmental challenges facing the globe. To be sure sprawl, urban sprawl, is heavily implicated in the high and growing level of resource consumption for transportation and everyday living, especially in America. But urban sprawl is not limited to the Global North. South African urban densities are low, at least as judged recently in comparison to other international settings (Todes, 2012). But urban living need not be all sprawled. Glaeser argues for the benefits of compact urban development, going so far as to say, «If the future is going to be greener, then it must be more urban» (Glaeser, 2011, p. 222). I have already argued above that urbanization is associated with slowing of the rate of childbearing, and lower fertility rates will hasten overall population growth rate diminution, thus augmenting whatever benefits accrue to have a moderated trajectory of overall human population growth on the planet in the coming decades. 
Environmental issues are very likely to see an interesting interplay between the Global North and the Global South. The North is highly urbanized already, while the South, as we have discussed, is in various stages of urbanization. Selected parts of the Global North (some European regions) are fairly compact and dense, which is (as above) often seen as salutary for the environment. Other parts of the Global North (say, the US and Australia) are much more sprawled. Thus the Global North offers competing models of urban residence to a heterogeneous Global South that will itself grow more urban. While there is no question that environmental impacts - from localized pollution to climate change - are anthropogenic, the detailed nature of the relationship is less well known. How much «bang for the buck»- how many units change in an environmental outcome per unit change in urban growth or migrant stock - is less well known at this stage. This concern raises the further issue of whether changes will take place on the adaptation or mitigation dimension. Even within a broad consensus that climate change will involve a worldwide effort and North-South cooperation, there is a continuing assessment that mitigation needs to be the intervention prong for the Global North, while adaptation will fall to the lower income countries of the Global South (Ott et al., 2008).

Migration is often implicated in health deterioration, or at a minimum health challenges. To be sure, migration is linked to a number of communicable diseases. Most notably, migration and other aspects of population mobility, both temporary and permanent, have been linked to HIV/AIDS. Again there is much to be said on both sides of the issue. Migration itself is stressful and it often separates a household (and its collective resources) at origin and destination. Migration - successful assimilation at destination can bring the higher standard of living and health improvements that are associated with increased household and community-wide incomes. At the same time the redistribution of persons toward urban areas (and the associated changes in occupation and life styles) may be associated with less salutary health outcomes such as obesity.

Particularly notable is the gain in health that can come for urban relocation in low-income countries. In one extensive study of Demographic and Health Surveys for 18 developing countries, Bocquier and colleagues found a distinct advantage in child survival in urban settings, although this advantage was muted or disappeared after controlling for a variety of other traits including migration status of the mother (Bocquier et al., 2011). At the more 
micro level, urbanization seems to bring with it better household drinking water quality, both indirectly (through the higher educational and socioeconomic composition of urban residents) and also directly, through public piped water provision (McGarvey et al., 2008). This result echoes the Bocquier et al. interpretation, that it is not urban density per se, but access to amenities and services that may account for the apparent urban advantage in health. Within this context, one must recognize the significant heterogeneity that exists in urban (and migrant) populations, and the heterogeneity of urban settings in which they live. All this suggests the importance of detailed data collection and careful modeling.

The overly facile and general connections among migration, urbanization, environment, and health would seem to be misplaced. The actual relations are likely to vary considerably over time, space and trait. The most recent Global Report on Human Settlements (UN, 2011) recognizes this with respect to the issue of climate change, even as it notes that we have yet to calculate accurately the contribution that cities make to global warming. Its conclusion points out the bidirectional implications. On the one hand urban living raises risks by exposing a large and concentrated population to environmental risks, such as those generated by extreme weather events. On the other hand, economies of scale may be able to reduce these risks of climate change (UN, 2011, p. 165). Much the same duality might be invoked for other consequences of urbanization. The conversation may be moving in a more productive direction.

\section{Selected Papers presented at the Quetelet Seminar}

The theme of the 2011 Quetelet Seminar, «Urbanization, internal migrations, and demographic behavior» is a welcome recognition of the importance of the topics I have discussed here. Even more, the particular conference presentations point to key issues and promising directions for the field.

Schumacher, Matthijs, and Moreels draw on unique historical data and novel techniques to help understand migration and family-building in Antwerp and Geneva, two cities with distinct sociodemographic profiles. The analysis tells us much about the variation in the processes of family-building, identifying some of the differences across the two cities as well as differences 
across background sociodemographic traits. They find clear evidence for the disruptive effect of migration on family building in both cities, with some companion evidence of adaptive fertility reduction among lowerstatus migrants from the countryside who settle in Geneva. Bree examines the 19th century historical experience also, looking closely at the case of Paris. Bree links urbanization to fertility decline in this historical period, a conclusion well worth recalling for contemporary studies of demographic dynamics in countries undergoing the demographic transition. Thierry Eggerickx, Jean-Paul Sanderson, and Rafael Costa also link fertility to spatial demography, in a paper focused on recent decades in Belgium. In work that is at the same time substantive and methodological, they examine the spatial history of fertility. Fortunately for other scholars, they find minimal bias in the understanding of fertility that might arise from spatial misallocation of events. Equally important, their substantive analysis indicates that migrant fertility behavior resembles more the destination than the origin population, lending credence to notions of demographic assimilation among migrants. Taken together, such studies reinforce our understanding of the tight link (often underappreciated even by demographers) between urbanization/migration and other components of population change.

Cédric Duchêne-Lacroix, Nicola Hilti, and Helmut Schad take up the fundamental question of residence itself. They examine the concept of multilocality, and they bring other demographic traits into the picture. Although their analysis focuses on the case of one country, Switzerland, the issue is quite broad. Concern about how best to attach people to place applies to many high-income countries, but these concerns also apply - especially under the rubric of temporary and circular migration - to low income countries as well. Adrien Remund also contributes a technical demographic analysis, one also with substantive results. Remund is concerned with length of residence, something arguably insufficiently captured, measured, and analyzed (compared to other demographic dynamics) in historical and present time. Using historical data for Geneva and drawing on technical epidemiological methods Remund traces the substantial variation in the average duration of stay in the city. This, in turn, has implications for the variability in the growth of Geneva over time, with periods of high mobility alternating with period of relative quietude.

Lerch's contribution turns to the very interesting case of Albania, a country that has recently gone through considerable change in it political economy, 
which has been accompanied by considerable demographic change. Lerch focuses on the recent sharp rise in Albanian urbanization, asking how it is linked to fertility dynamics. Intriguingly, and somewhat in contrast to the historical European cases mentioned above, Lerch find that migration is not linked to more rapid travel along the path of demographic transition. While Albania has experienced very large rural exodus, this has not been accompanied by a commensurate shift in family building dynamics. Rossier and co-authors shift attention to sub-Saharan Africa, a region of concern for its level of development and the yet-unclear role that urbanization may play in health outcomes within the continent. They analyze Demographic and Health Surveillance System data in Burkina Faso to predict health outcomes and their differentials by migrant status. They find that, despite some socioeconomic disadvantages of rural-urban migrants, the children of these migrants do not exhibit noticeably inferior health outcomes. For the adult migrant population, however, outcomes were mixed, with the migrants sometime better off and sometimes worse off than the comparison group of Ouagadougou urban residents.

\section{Issues for the future}

Trends in Geographic Mobility. The absolute number of internal and international migrants is most assuredly going to increase in coming years. Rates of flow of internal and international migrants are more difficult to project, but these rates of geographic mobility may well also increase through the same upcoming period of time. The expansion of social networks, the availability of the sufficient resources to initiate migration and overcome the migration-development paradox, improvement in the technology of transportation and communication, and further trends in globalization of trade suggest movement in this direction. On the other hand, the modest increase in international migrants - at least according to UN estimates - over the last several decades, suggests that the proportionate flow might not be as large as some dramatic discussions of globalizations would suggest. While there will undoubtedly be pressure to project the number migrants and ancillary flows (remittances, return migration, investment), these will be notoriously difficult. 
Very helpful analysis for policy and planning can come from a more comprehensive accounting and analysis of the demography of migration and of its link to economic development. Knowledge is still quite limited in this regard. Studies of remittances and poverty reduction for a wider set of societies would do much to clarify the role of these monetary flows in development. A better understanding of the determinants of individual international migration (home household conditions, visa access, and refugee status) would also do much to fill out the picture. Much knowledge would be gained from more longitudinal information on the migrants, historical and contemporary, including information about the level-of-living circumstances at origin and destination.

International Migration versus Internal Migration. International and internal migration have "grown» up separately. Recapitulating the earlier discussion, I argue that the parallel roles that international and internal migration play in the population distribution landscape should be more clearly recognized in the demographic dynamics of the 21st century. Doing so would help scholars and policy-makers develop a response that integrates the experience Global North and the Global South. Researchers have an opportunity now to tap information sources in one realm to inform the other, to mutual benefit. They should grasp this opportunity and there are already optimistic signs that this is happening. While at some purely conceptual level, one can identify clear parallels - demographic, social, and economic between internal and international migration, they are clearly not equivalent. Determinants and composition of the flows vary, and of course the policy setting for managing migrants and settlers differs.

Data Needs. Given the scale of migration anticipated in the 21st century and the increasing share of demographic dynamics population redistribution will place on overall demographic dynamics, it is worth improving the database for analysis and policy. Urban scholars have often commented on the need to improve demographic statistics that relate to urbanization and population distribution (Montgomery et al., 2003; see also Cross et al., 2006). While analysts have been very resourceful in gathering and tabulating available data on migratory flows (witness the contributions to Quetelet Seminar!), the state of the data archive is still deficient, when compared with other areas of population and development. Consider, by contrast, the progress in the medical and public health community in establishing since the 1950s a consistent classification diseases and illness, and more system- 
atic collection of such data across a wide array of countries. For migration and urbanization analysts, more consistent collection and promulgation of census data - an especially relevant concern for low-income countries would produce substantial benefits. Serious thought should be given to the value of longitudinal survey - which may be quite general in purpose - that would be designed to capture movement from region to region, from rural to urban, and from place to place, whether that move is within a country's borders or across an international border. The technical skills, concepts, and willingness is all present in the research community; it is time to go to work and move migration into century 21 .

\section{References}

AnNez P. C., Buckley R. M. (2006), «Urbanization and Growth: Setting the Context», SPENCE et al. (eds.) Urbanization and Growth, Washington, World Bank 2009.

Alba R., SLOAN J., Sperling J. (2011), «The Integration Imperative: The Children of Low-Status Immigrants in the Schools of Wealthy Societies", Annual Review of Sociology, 37, pp. 395415, http://dx.doi.org/10.1146/annurev-soc-081309-150219.

Barban N., White M. J. (2011), "Immigrants' Children's Transition to Secondary School in Italy», International Migration Review, 45 (3), pp. 702-726, http://dx.doi.org/10.1111/ j.1747-7379.2011.00863.x.

BOCQUIER P. (2005), «World Urbanization Prospects: An Alternative to the UN Model of Projection Compatible with Urban Transition Theory», Demographic Research 12 (9), pp. 197236, http://dx.doi.org/10.4054/DemRes.2005.12.9.

Bocquier P., Mukandila A. (2011), "African Urbanization Trends and Prospects», African Population Studies, 25 (2), pp. 337-361, http://dx.doi.org/10.11564/25-2-235.

Bocquier P., Traoré S. (2000), Urbanisation et dynamique migratoire en Afrique de l'Ouest. La croissance urbaine en panne, Paris, L'Harmattan.

BongaARTS J., Sinding S. (2011), "Population Policy in Transition in the Developing World», Science, 333, pp. 574, http://dx.doi.org/10.1126/science.1207558.

BROCKERHOFF M. (1999), "Urban Growth in Developing Countries: A Review of Projections and Predictions», Population and Development Review, 25, pp. 757-778, http://dx.doi.org/ 10.1111/j.1728-4457.1999.00757.x.

Cross C. et al. (eds) (2006), Views on Migration in Sub-Saharan Africa, Cape Town, HSRC Press. 
DURANTon G. (2006), «Are Cities Engines of Economic Growth and Prosperity for Developing Countries?», SPENCE et al. (eds), Urbanization and Growth, Washington, World Bank 2009.

Glaeser E. (2011), Triumph of the City, NY, Penguin.

Grimm N. B., faeth S. H., Golubiewski N. E., Redman C. L., Wu J., Bai X., Briggs J. M. (2008), «Global Change and the Ecology of Cities», Science, 319 (5'864), pp. 756-760.

DE HAAS H. (2008), "The Myth of Invasion: The Inconvenient Realities of African Migration to Europe», Third World Quarterly, 29, pp. 1305-1322, http://dx.doi.org/10.1080/ 01436590802386435.

Dyson T. (2010), Population and Development: The Demographic Transition, London, Zed.

Huntington S. P. (2004), Who Are We: The Challenges to America's National Identity, Simon \& Schuster.

Kosinski L. A., Clarke J. L. (1982), «African Population Distribution. Trends Patterns and Policies», J. L. ClARKE, L. A. KosInSKI (eds), Redistribution of Population in Africa, London, Heinemann.

MARTINe G. et al. (2008), The New Global Frontier, Earthscan 2008.

MARTINE G. (2011), «Preparing for Sustainable Urban Growth in Developing Areas», United Nations Population Division, Population Distribution, Urbanization, Internal Migration and Development: An International Perspective, NY.

Makinwa-Adebusoye P. (1992), "The West African Migration System», M. KRITZ, L. L. LIM, H. ZLOTNIK (eds), International Migration Systems, NY, Oxford.

McGarvey S., Buszin J., Reed H., Rahman Z., Andrzejewski C., White M., Awusabo-Asare K. (2008), "Community and Household Determinants of Water Quality in Coastal Ghana», Journal of Water and Health, 6 (3), pp. 339-349, http://dx.doi.org/10.2166/wh.2008.057.

McNeill W., Adams R. S. (eds) (1978), Human Migration: Patterns and Policies, Bloomington, Indiana University Press.

Migration Policy Institute (MPI) (2012), Data Hub, www.migrationinformation.org/ datahub/.

Montgomery M. (2008), "The Urban Transformation of the Developing World», Science, 319 (5'864), $761 \mathrm{p}$.

Montgomery M. et al. (2003), "Panel on Urban Dynamics, National Research Council», Cities Transformed: Demographic Change and its Implications in the Developing World, Washington DC, National Academy Press.

Myers D., Cranford C. J. (1998), «Temporal Differentiation in the Occupational Mobility of Immigrant and Native-Born Latina Workers", American Sociological Review, 63, pp. 68-93, http://dx.doi.org/10.2307/2657478.

New York Times (2011), "Swedes Begin to Question Liberal Migration Tenets», 26/02/11. 
Ott H. E., Sterk W., Watanabe R. (2008), «The Bali Roadmap: New Horizons for Global Climate Policy», Climate Policy, 8 (1), pp. 91-95, http://dx.doi.org/10.3763/cpol.2007.0510.

Population Reference Bureau (2011), World Population Data Sheet 2011, www.prb.org.

Poston D. L., Zhang L. (2008), «Ecological Analyses of Permanent and Temporary Migration Streams in China in the 1990s», Population Research and Policy Review, 27, pp. 689-712, http://dx.doi.org/10.1007/s11113-008-9094-5.

Preston S. H. (1979), «Urban Growth in Developing Countries: A Demographic Reappraisal», Population and Development Review, pp. 195-215, http://dx.doi.org/10.2307/1971823.

Preston-Whyte E. et al. (2006), «African Migration in the Twenty-first Century: Conclusion», M. Tienda, S. Findley, S. Tollman, E. Preston-Whyte (eds), Africa on the Move, Johannesburg, Wits U Press.

Pritchett L. (2006), Let Their People Come: Breaking the Gridlock on Global Labor Mobility, Washington DC, Center for Global Development.

Reed H. E. (2012), "Moving Across Boundaries: Migration in South Africa, 1950-2000», Demography, Published online 6/09/12.

SKeLDon R. (2008), «International Migration as a Tool in Development Policy: A Passing Phase?», Population and Development Review, 34 (1), pp. 1-18, http://dx.doi.org/10.1111/ j.1728-4457.2008.00203.x.

Spence M., AnNez P. C., Buckley R. M. (eds) (2009), Urbanization and Growth, Washington, World Bank.

TACoLI C. (2008), "Links Between Rural and Urban Development in Africa and Asia» United Nations Population Division, Population Distribution, Urbanization, Internal Migration and Development: An International Perspective, NY.

TACoLI C. (2010), "Population Dynamics and Climate Change: What Are the Links?», Journal of Public Health, 32, June, pp. 150-156.

TODES A. (2012), «Urban Growth and Strategic Spatial Planning in Johannesburg, South Africa», Cities, 29, pp. 158-165, http://dx.doi.org/10.1016/j.cities.2011.08.004.

United Nations [Commission on Population and Development] (2008), World population monitoring, focusing on population distribution, urbanization, internal migration and development, Report of the Secretary-General [E/CN.9/2008/3], NY, United Nations.

United Nations, Department of Economic and Social Affairs, Population Division (2006), Trends in Total Stock Migrants: The 2005 Revision. www.un.org/esa/population/publications/migration/UN_Migrant_Stock_Documentation_2005.pdf, Accessed 6/06/13.

United Nations, Department of Economic and Social Affairs, Population Division (2009), Trends in International Migrant Stock: The 2008 Revision, United Nations database, POP/DB/MIG/Stock/Rev.2008, http://esa.un.org/migration/p2k0data.asp. Accessed $5 / 06 / 13$. 
United Nations [Population Division] (2006), World Urbanization Prospects: The 2005 Revision, NY, United Nations.

United Nations [Population Division] (2008), An Overview of Urbanization, Internal Migration, Population Distribution and Development In The World, New York, United Nations, January.

United Nations [Population Division] (2011), World Urbanization Prospects: The 2011 Revision, http://esa.un.org/unup/index.html, Accessed 4/06/13.

United Nations [Population Division], Department of Economic and Social Affairs, Population Division (2011), International Migration Report 2009: A Global Assessment, United Nations, ST/ESA/SER.A/316.

United Nations [UNFPA] (2011), State of World Population 2011: People and Possibilities in a World of 7 billion, New York, United Nations.

WATers M. C., Jiménez T. R. (2005), «Assessing Immigrant Assimilation: New Empirical and Theoretical Challenges», Annual Review of Sociology, 31, pp. 105-125, http://dx.doi.org/ 10.1146/annurev.soc.29.010202.100026.

White M. J., JiANG L. (2008), "Migration, Urbanization and Spatial Dispersion in China», Manuscript, Presented to the Population Association of America.

White M. J., Lindstrom D. P. (2005), «Internal Migration», D. Poston, M. MickLIN (eds), Handbook of Population, Kluwer, (11), pp. 311-346.

White M. J., Mberu M. U., Coluinson M. (2008), «African Urbanization: Recent Trends and Implications», G. MARTINE et al. (eds), The New Global Frontier: Cities, Poverty and Environment in the 21st Century, London, Earthscan, pp. 301-316.

White M. J., Muhidin S., ANdrzejewski C. S., TAgoe E., Reed H., KNIGHT R. (2008), «Urbanization and Fertility: An Event-History Analysis of Coastal Ghana», Demography, 45, pp. 803-816, http://dx.doi.org/10.1353/dem.0.0035.

World Bank (2006), Global Economic Prospects: Economic Implications of Remittances and Migration, Washington, DC, World Bank.

ZaChariah K. C., Conde J. (1981), Migration in West Africa: Demographic Aspects, Washington, DC, World Bank. 